\title{
GIS-based Flood Risk Assessment in the Urban Catchment of Uyo Metropolis, Nigeria
}

\author{
Nsiegbe, Dickson Kinikawo ${ }^{1}$, Weli, Vincent E. ${ }^{2}$, Chukwu-Okeah, Gift O. ${ }^{3}$, Eludoyin, Olatunde S. ${ }^{4}$, Abali, Temple \\ Probyne $^{5}$, Inko-Tariah, Ibiso Michael ${ }^{6} \&$ Nkii, Lucky Baripara ${ }^{7}$ \\ 1,2,3,4 Department of Geography and Environmental Management, University of Port Harcourt, Nigeria \\ ${ }^{5,6}$ Department of Geography and Environmental Management, Faculty of Social Sciences \\ Rivers State University, Port Harcourt, Nigeria \\ ${ }^{7}$ Institute of Geosciences and Environmental Management, Rivers State University, Port Harcourt, Nigeria \\ Emails: Dicksonnsiegbe@,Gmail.Com
}

\begin{abstract}
Flood occurs as a result of rising global temperatures, more precipitation, increased runoff, and an increase in the rate of urban flooding. The goal of this research is to calculate the flood risk assessment of a selected urban catchment in the Nigerian metropolis of Uyo. Secondary data were obtained from Landsat images of the study area using a correlational research design. Using supervised categorization of landuse in the area, the watershed pattern, landuse/landcover, and inundation level were determined using the area's Digital Elevation Model. The study also used a GIS-assisted computer simulation of storm water created by enhanced DEM to assess storm water level and inundation as a function of landuse/landcover change. Storm water generation assessment, inundation modeling, assessment of land cover and level of inundation, and evaluation of flash flood susceptibility using modeled inundation were among the hydrological models and techniques used to analyze the data. The findings revealed that Uyo has a number of streams with varying flow lengths. Uyo has 21 sub-basins, according to the study. In uyo, the total runoff was greater (0.74) inches. In Uyo, the rate of change in catchment behavior, such as catchment precipitation, node flooding, and runoff, increased with the time of day, whereas the rate of change in runoff volume varied somewhat. The hydrograph was not wider because the sections of Uyo metropolitan that were prone to moderate and high floods were higher (78.03 percent ). Based on these findings, the study suggests that better city design is needed to control the impact of flooding in the study area. To prevent the loss of life and property, areas prone to moderate and high flood vulnerability should be closely monitored and secured.
\end{abstract}

Keywords: Catchment, Flood, Urban, Vulnerability

\section{Introduction}

The rate of urban flash floods is increasing as global temperatures rise, seasonal shifts occur, and precipitation levels rise, resulting in increased run-off (Sunnin, Saro, Moung-Jin and HungSup, 2018). Heavy rains, typhoons, floods, and other weather events disrupt the hydrological system, putting more strain on drainage systems, water treatment plants, and sewage treatment plants in metropolitan areas (Muneerudeen, 2017). As a result of the high amounts of rainwater in rivers, the risk of flooding increases significantly. A flash flood is defined as a flood that occurs suddenly, lasts only a few minutes, and has a reasonably high peak discharge (Ismail, 2015). Flash floods happen quickly, usually within an hour of rainfall, and are often accompanied by landslides, mud flows, bridge collapse, and property damage (Hapuarachichi, Wang \& Pagano, 2019).

In recent years, floods have been predicted using hydrologic and hydraulic models, which required large-scale data that was not available. Before 2000, according to Aneesha, Shashi, and Meshapam (2019), the use of Geographic Information System (GIS)-based methods for flood risk and hazard evaluation was uncommon. As a result, it is critical for municipal and urban planning specialists to identify and manage the natural risk posed by flash floods in order to 
plan for the future. With the advancement of computer technology, disaster management and mitigation authorities can now accurately predict where floods will occur and how severe they will be. Many studies have been done in the past and recently to map floods in many nations in order to estimate the amount of flash flood and inundation in order to make flood hydrographs and flood maps to demonstrate the level of hazard as a result of run-off, such as in the United States (Mastin, 2009), China (Liang, Yongli, Hongquan, Daler, Jingmin and Juan, 2011), Egypt (El Bastawesy, White and Nasr, 2009; Ghomein, Arnell and Foody, 2002), Saudi Arabia (Sand, 2010; Dawod, Mirza \& Al-Ghandi, 2011), India (Bhatt, Rao, Manjushree and Bhanumurthy, 2010) \& Ghana (Forkuo, 2011).

The water surface elevation associated with flood events can be computed using a variety of ways in flood simulation models. Some of these models employ a one-dimensional (ID) method, while others employ a two-dimensional (2D) approach, while yet others employ both ID and 2D simulation. HEC-RAS version 5.0.3 was issued by the US Army Corps of Engineering Hydrologic Engineering Center (HEC) in 2015 using the HEC-RAS model, which performs ID stable and unsteady calculations as well as 2D and unsteady flow calculations to predict flash flood. HEC-HMS model, Digital Elevation Model (DEM), and land satellite imagery over metropolitan centers are some of the other models used to investigate flood threats.

Flash floods are a prevalent danger in the Niger Delta region of Nigeria, as well as other deltaic locations across the world. This is due to the fact that the majority of the region is below sea level. The deltaic nature of the drainage basin in the region, as well as the fact that the entire area is within the flood plain, as well as increasing urban population pressure on the area's urban environment without effective land use planning, have made the region flash flood prone. There is substantial worry about the incidence of flash floods in the area as a result of increased land use and land cover change, increased human developmental activities, strong rainfall, and a high rate of runoff. Given that a study on flash flood risk assessment in the Niger delta metropolis is being conducted in a few selected metropolitan centers in the region.

Because the qua, Ibew, and Itu rivers, as well as other creeks and streams, drain the Uyo metropolitan area, these two cities were chosen for this study because they have gluts of swampy basins cross-crossed by a plethora of rivers and creeks (Amangabara and Obenade, 2015 and Eyinla and Ukpo, 2006) that lie directly in the wet equatorial climatic belt (Amangabara \& Obenade, 2015). Second, the metropolis of Uyo was chosen for this study because to its large urban population, which makes it prone to flash floods. According to the National Population Commission (NPC) (2019), Uyo has a population of 1,773,000, Yenegoa has a population of 470,800 , Benin city has a population of $1,676,000$, Calabar has a population of 555,000 , Asaba has a population of 407,126 , and Warri has a population of 814,000 . As a result, the Uyo metropolis, which is prone to flash floods, has been a cause of concern for urban planners.

In recent years, flash floods have had disastrous effects in metropolitan areas, resulting in the deaths of thousands of people, the destruction of property, and the relocation of millions more people. Increased urbanization, landuse and land cover changes, unregulated development, human attraction and invasion of flood plains and wetlands, and the blocking of river channels, splits, and drainages have all been linked to the incidence of urban flash floods. A key concern is the absence of accurate demarcation of probable flash flood and inundation areas in order to develop flood maps that depict the actual amount of inundation of the flood plain. Poor landuse 
regulation and urban planning, a lack of awareness of landuse and land cover changes, and a lack of experience in using GIS to model flash flood risk assessment all contribute to the problem.

The following research questions have been put up to help the study achieve its goal:

1. What are the differences in storm-water generation between each of the cities under consideration?

2. What is the possible amount of inundation across the research area due to a flash flood?

3. What effect does land use and cover have on inundation levels throughout the study area?

4. What is the pattern of vulnerability to flash floods in these areas?

The study's aim is to figure out how vulnerable certain catchments in Uyo, Nigeria are to flooding. Specific objectives include to

1. Model the variation in storm-water generation throughout the research area's cities.

2. Simulate the possibility for flash flood inundation across the research area's cities.

3. Assess the impact of flash flood flooding on land use and cover across cities.

4. Simulate the susceptibility of a given metropolitan catchment to local flash flood patterns.

\section{Literature Review}

The Uyo Metropolis is located between latitudes $4032^{\prime} \mathrm{N}$ and $5033 \mathrm{~N}$ of the equator, and longitudes $7 \mathrm{o} 25^{\prime} \mathrm{E}$ and $8025^{\prime} \mathrm{N}$ of the Greenwich Meriden (Census, 2006). The state capital of Akwa Ibom is Uyo. The population of Uyo metropolis is 427,873 (NPC), with an estimated population of 7124440 . (2019 Population Estimate). It covers $362 \mathrm{~km} 2$ and has a density of $1,200 \mathrm{~km} 2(1,300$ per square meter).

Uyo metropolitan has a unique characteristic climate, with an average annual rainfall of $250 \mathrm{gmm}$ and a temperature of $26.4 \mathrm{oC}$. (Oyegun, 1994). The research area's relief and drainage are such that it lies within the coastal belt, which is dominated by low-lying coastal plans that are structurally related to the Agbada and Akata formulations. Because the area is low lying coastal, the flow of water and surface runoff has kinks in the flow pattern. Coastal lowlands are crisscrossed by a labyrinth of swamp, creeks, and waterways, indicating a paucity of firm and vast land mass. The area's soil and geology are made up of a variety of super final deposits that lie on top of thick tertiary sandy and clayey deposits that can be over 100 meters thick in spots. The area's persistent high rainfall and warmth promote severe chemical weathering of the rocks, resulting in the development of clay minerals that are found across the region (Oyegun, 1994). The soils in the area are divided into two categories: those produced from sediments and those formed on younger quaternary and recent alluvium.

\section{Research Method}

\subsection{Methods of Data Collection}

The data for the study was gathered using a computer simulation supplemented by a Geographic Information System (GIS) from the United States Geological Survey (2020). Storm water was generated across the study region using an upgraded DEM created for the area to indicate the level of inundation depending on land cover, watershed demarcation, and participation, as well as the inundated area's susceptibility level.

The research design was also used in this study. This study employed a correlational design 
approach to assess the strength of the association between runoff (stormwater) and the associated risk of vulnerability (inundated impact) on flood-prone locations in the study area. As a result, the study's data is secondary data created from landsat imageries of the study area, which depict the area's digital elevation and water shed pattern, as well as landuse and landcover maps, which provide a supervised classification of landuse in the area.

3.2 Method of Data Analysis

In order to meet the study's objectives, the data was evaluated utilizing hydrological models and modeling methodologies.

1. Storm Water Generation Assessment: The flood hydrograph modeling was used to predict storm water generation in the small catchment, and the steps were as follows:

a) Gather demographic information for the research area.

b) Use GIS software to run a model utilizing DEM data to slow the storm water created.

c) Using multi-criteria evaluation approaches, weigh and overlay DEM data under the principle of pair-wise comparison of storm water runoff against rainfall intensity and terrain pattern.

d) Calculate the volume of runoff that will be plotted on the flood hydrograph. Amro et al (2019) used this technique to assess flash flood risk in an urban watershed in Taiah and the Islamic University Campus of the Kingdom of Saudi Arabia.

2. Inundation Modeling

To evaluate the possible level of inundation of flash flood across cities, watershed/catchments modeling was utilized to determine the catchment/watershed and carry out hydrological modeling utilizing soil, climate, elevation, and drainage data for the research area. In this current study, the GIS Software will be utilized to estimate rainfall runoff across the study region, as used by Amro et al (2019) and Lian et al, (2017), and will be used to identify the catchments across the cities. This will depict the flood and runoff simulation inflow as well as the probable amount of inundation in the research region.

3. Assessment of Relationship between Land Cover and level of Inundation

The following steps were taken:

a) Obtain the city's land cover.

b) Recreate the level of material flow inundation on land covers.

c) Compare the level of inundation based on land cover.

4. Flash Flood Vulnerability Assessment Using Modeled Inundation

Jenk's classification was used to determine vulnerability based on the level of inundation modeled. Vulnerability classifications would be divided into five categories: Very High (VH), High (H), Moderate (M), Low (L), and Very Low (VL). The cities would be divided into sections based on their hydrological characteristics. Each hydrological unit would be divided into small catchments/watershed units, with the catchments/watershed units being divided into hydrological response units (HRUs), from which proportions of various land uses and land covers could be calculated. Woubet and Belachew (2011) used this method to assess flood danger and risk in Fogera Woreda, northwest Ethiopia, utilizing GIS and remote sensing.

\section{Findings and Discussions}

The total length of streams in Uyo metropolitan was 312894.25 meters, with an average length of 1246.59 meters. In the Uyo metropolitan, there were 251 streams, with the maximum flow length of $0.14 \mathrm{~m}$. 
Table 1: Stream Parameters

\begin{tabular}{ll}
\hline Stream Parameters & Uyo \\
\hline Total Stream Length (m) & 312894.25 \\
Average Stream Length (m) & 1246.59 \\
Number of Streams & 251 \\
Standard Deviation & 469.16 \\
Minimum (m) & 460.64 \\
Maximum (m) & 3261.87 \\
Highest Flow Length (m) & 0.14 \\
\hline
\end{tabular}

Source: Researcher Analysis, 2020

In Uyo metropolis, the area of sub-basin ranged from 1187688.18 to 92699584.59 sqm with the mean value of $11845065.10 \mathrm{sqm}$.

Table 2: Stream Parameters

\begin{tabular}{ll}
\hline Sub Basin Parameters & Uyo \\
\hline Total Number of Basins & 21 \\
Total Area (Sq. m) & 248746367.20 \\
Minimum (Sq. m) & 1187688.18 \\
Maximum (Sq. m) & 92699584.59 \\
Average Area (Sq. m) & 11845065.10 \\
Standard Deviation (Sq. m) & 19630077.58 \\
\hline
\end{tabular}

Source: Researcher's Analysis, 2020 


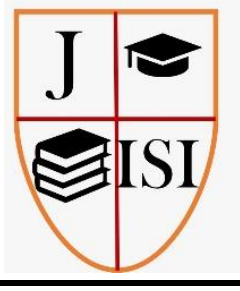

International Journal of information Systems and Informatics e-ISSN 2746-1378 Vol. 2, No.4 December 2021

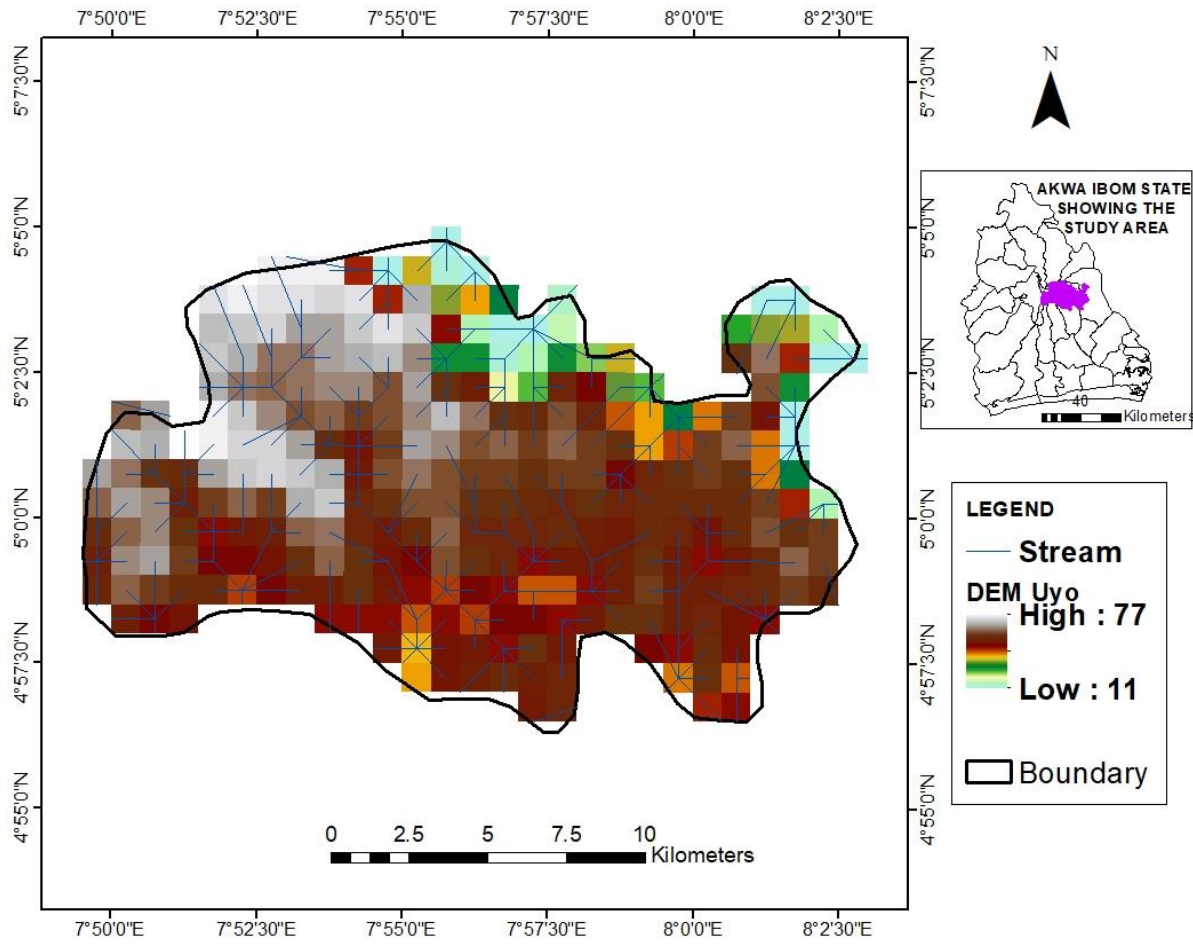

Fig. 1: DEM of Uyo and Streams

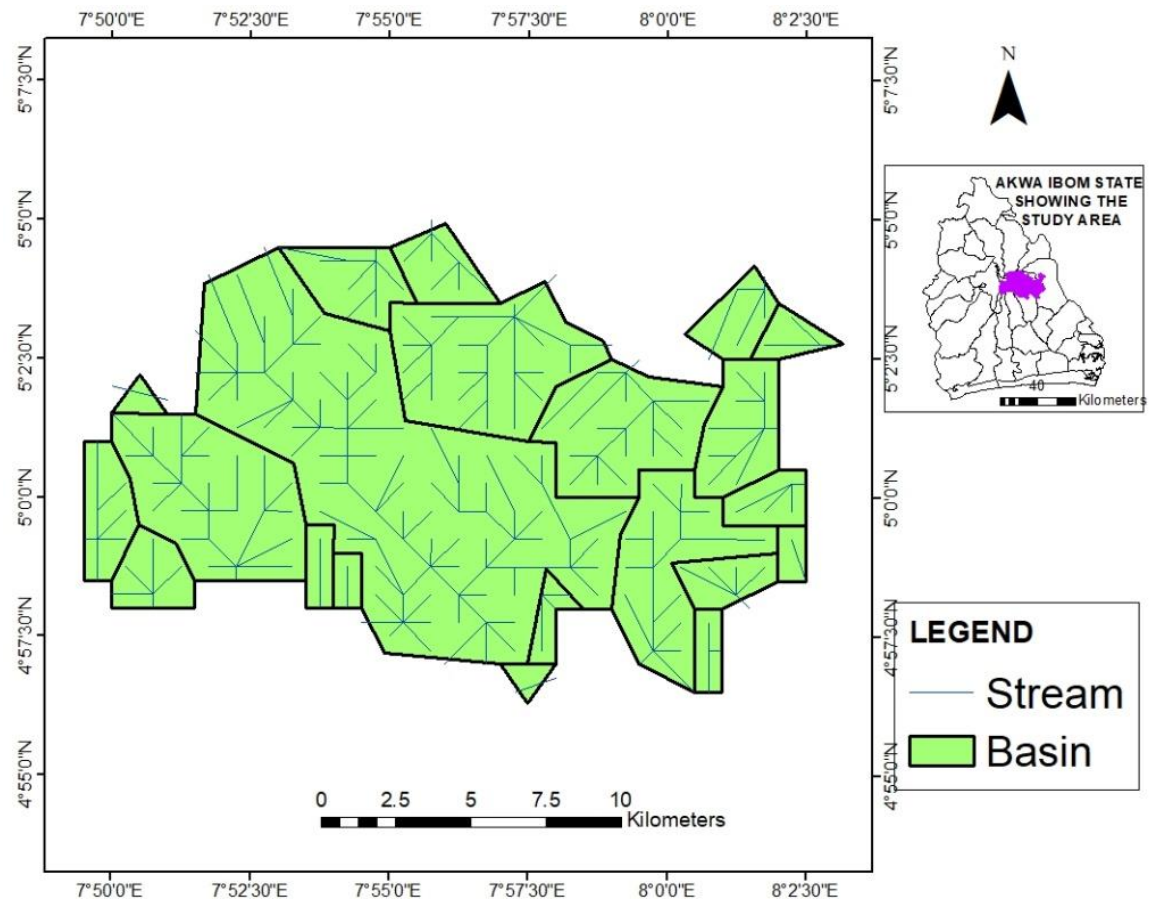

Fig. 2: Streams and Basins 


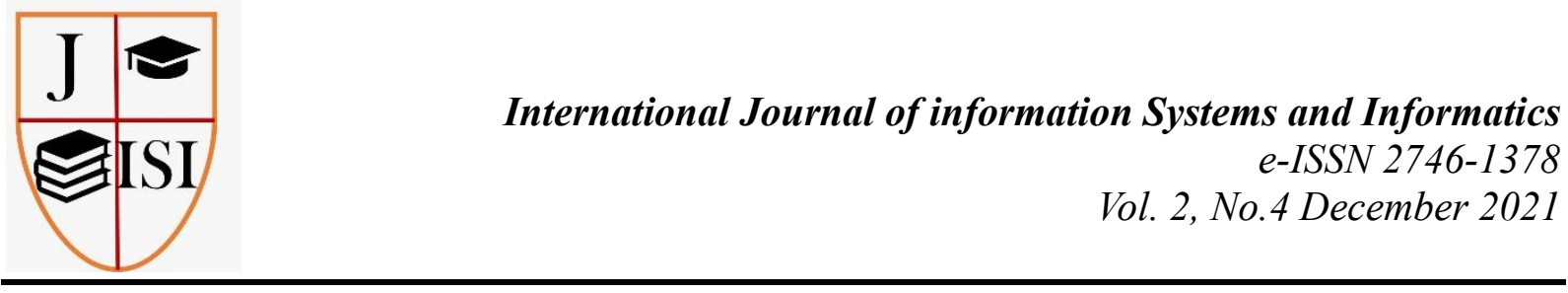

Vol. 2 , No.4 D

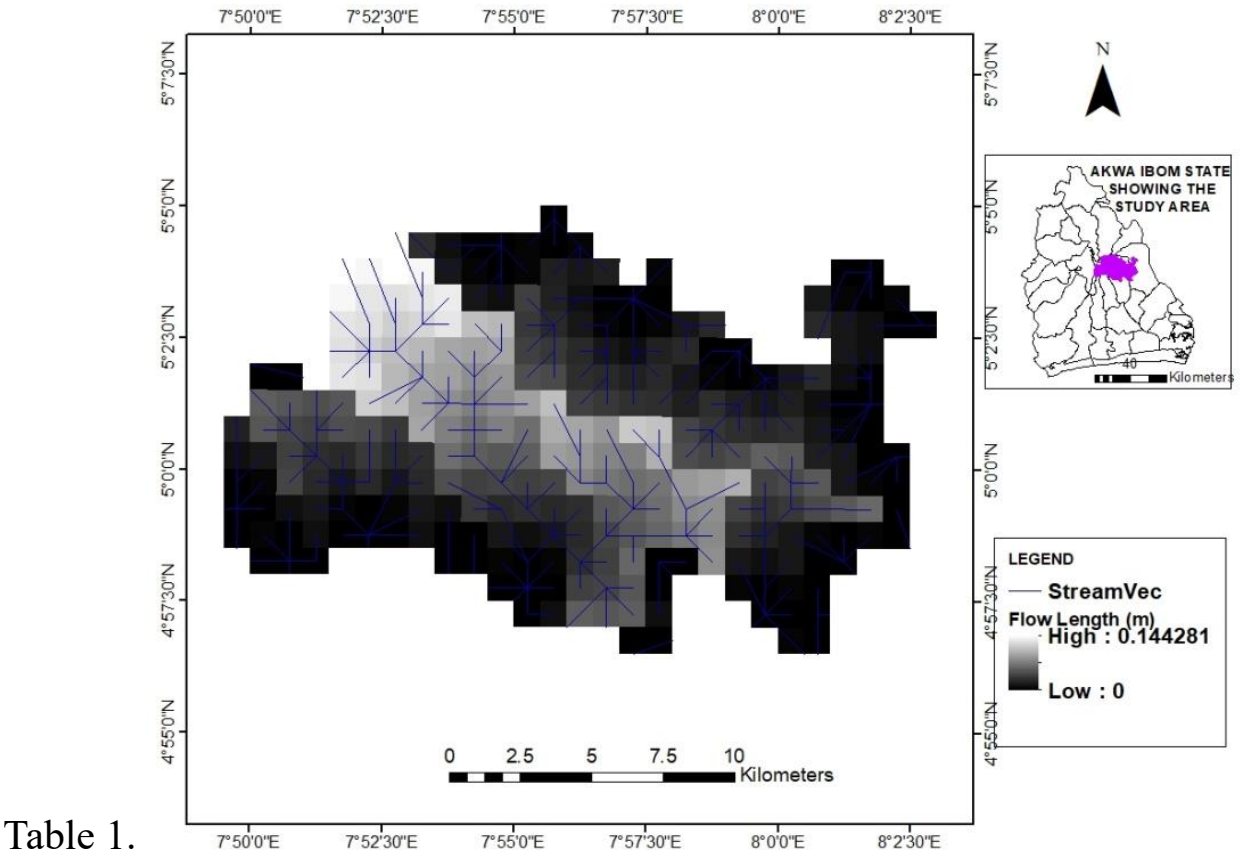

Fig. 3: Flow length of Flood in Uyo Metropolis

\section{Storm Water Generation in Uyo Metropolis}

Table 4.8 depicts the simulated sub-catchment runoff in Uyo Metropolis, which was generated using eight sub-catchments (Figure 4.11). The total precipitation in each sub catchment was 0.03 inch, while the total infiltration was 0.01 inch, as shown. The total runoff was $0.02 \times 106$ gal, with $0.01 \times 106 \mathrm{CFS}$ as the peak.

According to the link flow study through the conduit or pipe given in Table 4.9, the conduit's maximum flow ranged from $0.01 \mathrm{CFS}$ in $\mathrm{C} 1, \mathrm{C} 3, \mathrm{C} 5$, and $\mathrm{C} 7$ to $0.04 \mathrm{CFS}$ in $\mathrm{C} 2$ and $\mathrm{C} 6$, with a flow hour of 6 hours. The conduits' maximum velocity ranged from 0 feet per second in $\mathrm{C} 1$ to 49 feet per second in C6. The conduit's greatest complete depth appeared to range from $0 \mathrm{ft}$ (C1) to $0.04 \mathrm{ft}(\mathrm{C} 2)(\mathrm{C} 8)$.

The flow frequency was 45.56 percent, with an average flow of $0.03 \mathrm{CFS}$, according to the outfall loading reported in Table 4.7. In Uyo Metropolis, the maximum flow was 3.64 CFS and the total amount of storm water was $0.05 \times 106$ gal.

Table 3: Sub-catchment Runoff in Uyo

\begin{tabular}{|c|c|c|c|c|c|c|c|c|c|c|}
\hline $\begin{array}{l}\text { Sub } \\
\text { catch } \\
\text { ment }\end{array}$ & $\begin{array}{l}\text { Total } \\
\text { precipitat } \\
\text { ion (in) }\end{array}$ & $\begin{array}{l}\text { Total } \\
\text { Runo } \\
\mathrm{n} \text { (in) }\end{array}$ & $\begin{array}{l}\text { Total } \\
\text { Evapora } \\
\text { tion (in) }\end{array}$ & $\begin{array}{l}\text { Total } \\
\text { Infiltrat } \\
\text { ion (in) }\end{array}$ & $\begin{array}{l}\text { Impervi } \\
\text { ous } \\
\text { Runoff } \\
\text { (in) } \\
\end{array}$ & $\begin{array}{l}\text { Perviou } \\
\text { s } \\
\text { Runoff } \\
\text { (in) } \\
\end{array}$ & $\begin{array}{l}\text { Total } \\
\text { Runof } \\
\mathrm{f} \text { (in) } \\
\end{array}$ & $\begin{array}{l}\text { Total } \\
\text { Runoff } \\
10^{\wedge} 6 \text { gal }\end{array}$ & $\begin{array}{l}\text { Peak } \\
\text { Runo } \\
\text { ff } \\
\text { CFS } \\
\end{array}$ & $\begin{array}{l}\text { Runof } \\
\mathrm{f} \\
\text { Coeff } \\
\end{array}$ \\
\hline S1 & 0.03 & 0 & 0 & 0.01 & 0 & 0.01 & 0 & 0.02 & 0.01 & 0.095 \\
\hline S2 & 0.03 & 0 & 0 & 0.01 & 0 & 0.01 & 0 & 0.02 & 0.01 & 0.095 \\
\hline S3 & 0.03 & 0 & 0 & 0.01 & 0 & 0.01 & 0 & 0.02 & 0.01 & 0.095 \\
\hline S4 & 0.03 & 0 & 0 & 0.01 & 0 & 0.01 & 0 & 0.02 & 0.01 & 0.095 \\
\hline S5 & 0.03 & 0 & 0 & 0.01 & 0 & 0.01 & 0 & 0.02 & 0.01 & 0.095 \\
\hline S6 & 0.03 & 0 & 0 & 0.01 & 0 & 0.01 & 0 & 0.02 & 0.01 & 0.095 \\
\hline S7 & 0.03 & 0 & 0 & 0.01 & 0 & 0.01 & 0 & 0.02 & 0.01 & 0.095 \\
\hline
\end{tabular}




\begin{tabular}{lllllllllll} 
S8 & 0.03 & 0 & 0 & 0.01 & 0 & 0.01 & 0 & 0.02 & 0.01 & 0.095 \\
\hline
\end{tabular}

Table 4: Link Flow in Uyo

\begin{tabular}{|c|c|c|c|c|c|c|c|c|}
\hline Link & Type & $\begin{array}{l}\text { Maximum } \\
\text { Flow } \\
\text { (CFS) }\end{array}$ & $\begin{array}{l}\text { Day of } \\
\text { Maximum } \\
\text { Flow }\end{array}$ & $\begin{array}{l}\text { Hour } \\
\text { Maximum } \\
\text { Flow }\end{array}$ & of & $\begin{array}{l}\text { Maximum } \\
\text { Velocity } \\
\mathrm{ft} / \mathrm{sec}\end{array}$ & $\begin{array}{l}\text { Maximum/ } \\
\text { Full Flow } \\
\end{array}$ & $\begin{array}{l}\text { Maximum } \\
\text { Full Depth }\end{array}$ \\
\hline $\mathrm{C} 1$ & CONDUIT & 0.01 & 0 & & $6: 00$ & 0 & 0 & 0 \\
\hline $\mathrm{C} 2$ & CONDUIT & 0.04 & 0 & & $6: 00$ & 4.07 & 0 & 0.03 \\
\hline $\mathrm{C} 3$ & CONDUIT & 0.01 & 0 & & $6: 00$ & 1.15 & 0 & 0.02 \\
\hline $\mathrm{C} 5$ & CONDUIT & 0.01 & 0 & & $6: 00$ & 2.3 & 0 & 0.02 \\
\hline C6 & CONDUIT & 0.04 & 0 & & $6: 00$ & 4.9 & 0 & 0.03 \\
\hline C7 & CONDUIT & 0.01 & 0 & & $6: 00$ & 1.15 & 0 & 0.02 \\
\hline $\mathrm{C} 8$ & CONDUIT & 0.02 & 0 & & $6: 00$ & 1.24 & 0 & 0.04 \\
\hline
\end{tabular}

Table 5: Node Inflow in Uyo

\begin{tabular}{|c|c|c|c|c|c|c|c|c|}
\hline Node & Type & $\begin{array}{l}\text { Maximum } \\
\text { Lateral } \\
\text { Inflow } \\
\text { CFS }\end{array}$ & $\begin{array}{l}\text { Maximum } \\
\text { Total } \\
\text { Inflow } \\
\text { CFS }\end{array}$ & $\begin{array}{l}\text { Day of } \\
\text { Maximum } \\
\text { Inflow }\end{array}$ & $\begin{array}{l}\text { Hour of } \\
\text { Maximum } \\
\text { Inflow }\end{array}$ & $\begin{array}{l}\text { Lateral } \\
\text { Inflow } \\
\text { Volume } \\
10^{\wedge} 6 \text { gal } \\
\end{array}$ & $\begin{array}{l}\text { Total } \\
\text { Inflow } \\
\text { Volume } \\
10^{\wedge} 6 \mathrm{gal} \\
\end{array}$ & $\begin{array}{l}\text { Flow } \\
\text { Balance } \\
\text { Error } \\
\text { Percent } \\
\end{array}$ \\
\hline $\mathrm{J} 1$ & JUNCTION & 0.01 & 0.01 & 0 & $6: 00$ & 0.000302 & 0.000302 & 0 \\
\hline $\mathrm{J} 2$ & JUNCTION & 0.01 & 0.04 & 0 & $6: 00$ & 0.000302 & 0.00203 & 0 \\
\hline $\mathrm{J} 3$ & JUNCTION & 0.01 & 0.04 & 0 & $6: 00$ & 0.000302 & 0.0023 & 0 \\
\hline $\mathrm{J} 4$ & JUNCTION & 0.01 & 0.01 & 0 & $6: 00$ & 0.000302 & 0.000302 & 0 \\
\hline $\mathrm{J} 5$ & JUNCTION & 0.01 & 0.02 & 0 & $6: 00$ & 0.000302 & 0.000879 & 0 \\
\hline J6 & JUNCTION & 0.01 & 0.01 & 0 & $6: 00$ & 0.000302 & 0.000302 & 0 \\
\hline $\mathrm{J} 7$ & JUNCTION & 0.01 & 0.01 & 0 & $6: 00$ & 0.000603 & 0.000603 & 0 \\
\hline Out1 & OUTFALL & 0 & 0.04 & 0 & $6: 00$ & 0 & 0.00228 & 0 \\
\hline
\end{tabular}

Table 6: Node Depth in Uyo

\begin{tabular}{|c|c|c|c|c|c|c|c|}
\hline Node & Type & $\begin{array}{l}\text { Average } \\
\text { Depth Feet }\end{array}$ & $\begin{array}{l}\text { Maximum } \\
\text { Depth Feet }\end{array}$ & $\begin{array}{l}\text { Maximum } \\
\text { HGL Feet }\end{array}$ & $\begin{array}{l}\text { Day of } \\
\text { Maximum } \\
\text { Depth }\end{array}$ & $\begin{array}{l}\text { Hour of } \\
\text { Maximum } \\
\text { Depth }\end{array}$ & $\begin{array}{l}\text { Maximum } \\
\text { Reported } \\
\text { Depth Feet } \\
\end{array}$ \\
\hline J1 & JUNCTION & 0 & 0 & 255.91 & 0 & $6: 00$ & 0 \\
\hline $\mathrm{J} 2$ & JUNCTION & 0.02 & 0.04 & 226.42 & 0 & $6: 00$ & 0.04 \\
\hline $\mathrm{J} 3$ & JUNCTION & 0.01 & 0.03 & 180.48 & 0 & $6: 00$ & 0.03 \\
\hline J4 & JUNCTION & 0.01 & 0.02 & 236.24 & 0 & $6: 00$ & 0.02 \\
\hline J5 & JUNCTION & 0.02 & 0.04 & 229.7 & 0 & $6: 00$ & 0.04 \\
\hline J6 & JUNCTION & 0.01 & 0.02 & 236.24 & 0 & $6: 00$ & 0.02 \\
\hline J7 & JUNCTION & 0.01 & 0.02 & 252.65 & 0 & $6: 00$ & 0.02 \\
\hline Out1 & OUTFALL & 0.01 & 0.03 & 111.58 & 0 & 6:00 & 0.03 \\
\hline
\end{tabular}

Table 7: Outfall Loading in Uyo

\begin{tabular}{lrrrr}
\hline Outfall Node & Flow Frequency (\%) & Avg Flow (CFS) & Maximum Flow (CFS) & Total Volume (10^6 gal) \\
\hline Out1 & 45.56 & 0.03 & 0.04 & 0.05 \\
\hline
\end{tabular}




\section{Sub Catchment Precipitation, Node Flooding and Linking Volume}

Figure 4.13 depicts the rainfall time series in Uyo Metropolis, which began to rise at 0 hours and peaked between the 18th and 20th hours of the day before declining.

Table 4.13, Figure 4.14 (1.00mins-01.15mins), Figure 4.15 (1.15mins-04.00mins), and Figure 4.16 depict the behavior of sub catchment conditions in terms of precipitation runoff, infiltration, node flooding, and link volume at various times of the day (04.00-06.00mins). The data revealed that as the time of day progressed, the sub-catchment precipitation increased from 0 in to 0.39 in. Moreover, the flooding and linking volumes followed a similar pattern throughout the day, albeit at different times. For example, node flooding began at 0.15 minutes (25 CFS) and grew to $75 \mathrm{CFS}$ at 1.00 minutes, while connecting volume fluctuated from $0 \mathrm{ft} 3$ to $460 \mathrm{ft} 3$. Figures 4.18 and 4.19, as well as Table 4.14, show sub-catchment precipitation, node flooding, and connecting volume for the Uyo Metropolis. Sub-catchment precipitation and node flooding both jumped quickly from 0.01 in to 0.05 in and 25 in to 50 in at 3 hrs.00 mins, according to the research.

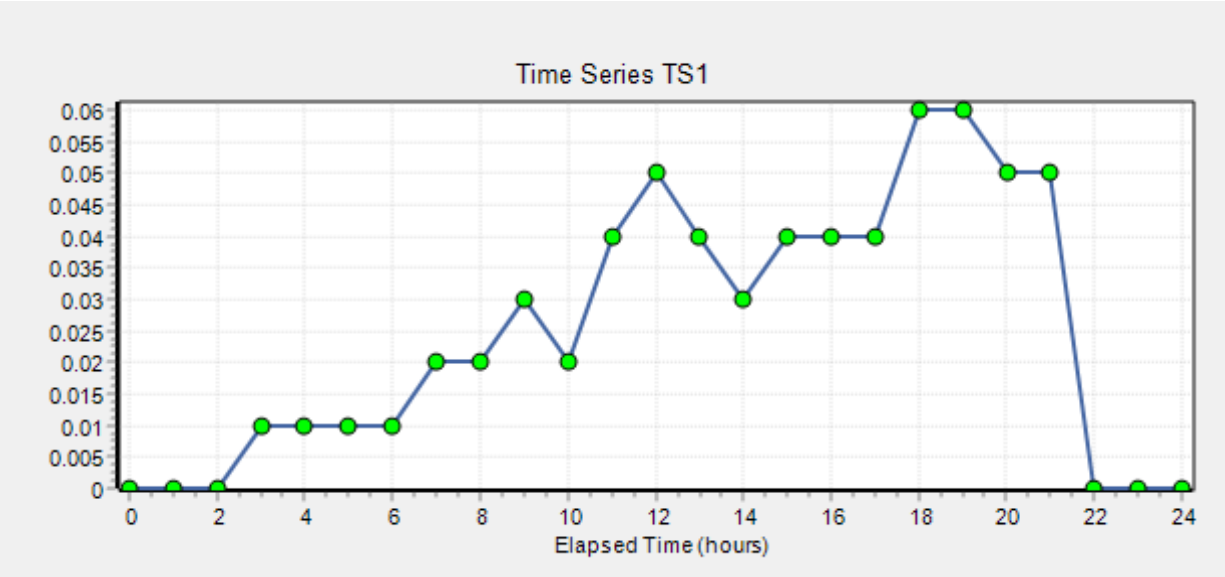

Fig. 4: Time Series of Precipitation Data in Uyo

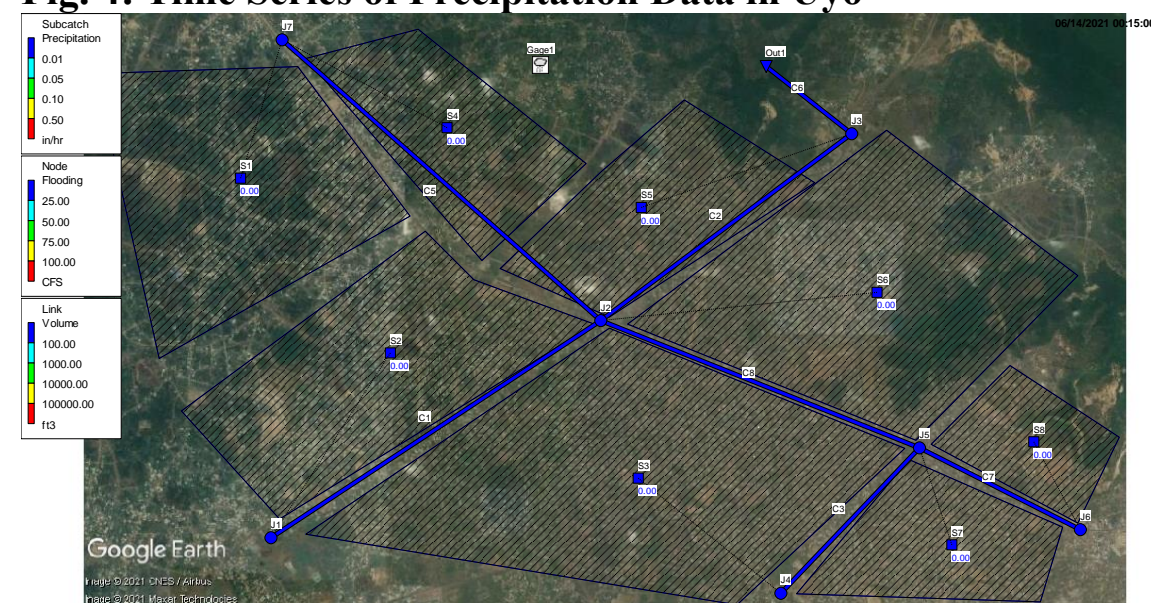

Fig. 5: Sub Catchment precipitation, Node Flooding and Link Volume in Uyo at 0.00 mins - 03.00 Mins 


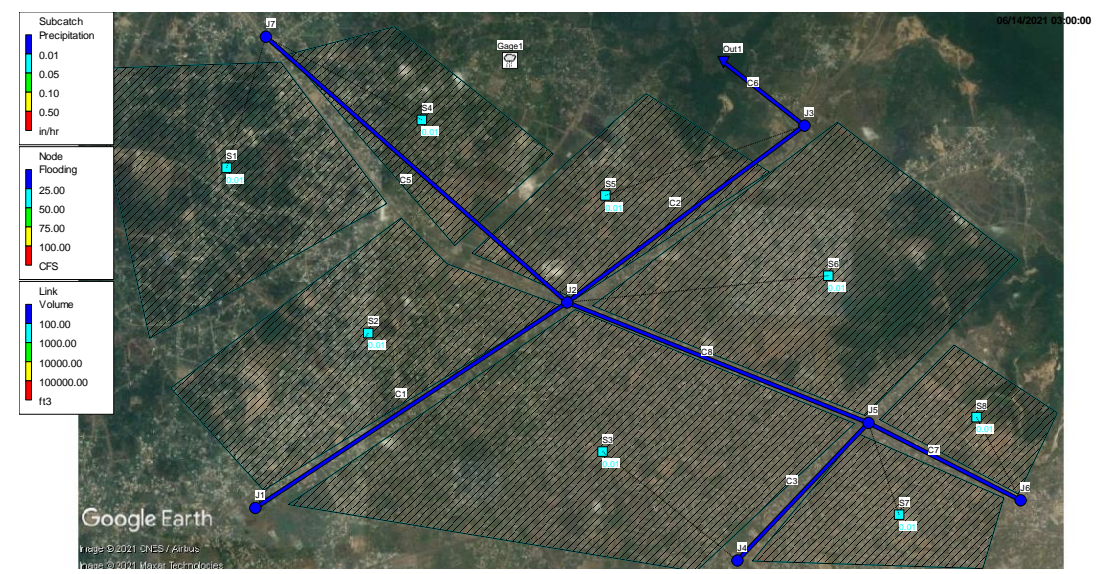

Fig. 6: Sub Catchment precipitation, Node Flooding and Link Volume in Uyo at 03.00 mins - 06hour.00 Mins

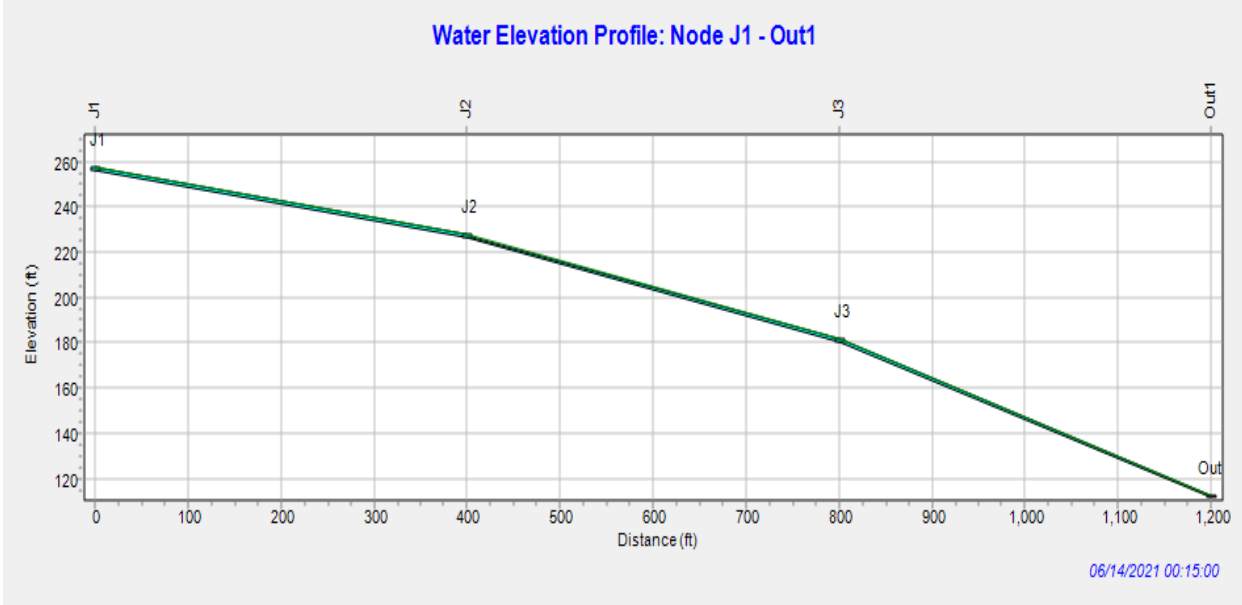

Fig. 7: Water Elevation Profile from Node 1 - Out 1 in Uyo

\section{Flood Vulnerability in Uyo Metropolis}

\section{Landuse Map Vulnerability}

The sensitivity of the landuse map to flooding was calculated using the vulnerability levels ascribed to each landuse in the Uyo Metropolis. The forms of landuse observed, as well as their spatial range, are explained in Table 4.24, Figure 4.45, and Figure 4.46. The built-up area $(141783308.91 \mathrm{~m} 2)$ has the largest spatial extent, followed by vegetation patches ( 50813320.29 $\mathrm{m}^{2}$ ). Farmlands/Sparse vegetation accounted for $35785889.00 \mathrm{~m} 2$, whereas waterbodies accounted for $26428311.14 \mathrm{~m} 2$. Built-up areas accounted for 55.64 percent, farmlands/sparse vegetation 14.04 percent, and waterbodies and vegetation patches respectively 10.37 percent and 19.94 percent. The investigation also revealed that the area with moderate flood susceptibility was 33.98 percent, while the area with severe flood vulnerability was 66.02 percent.

\section{Table 8: Landuse Classification in Uyo}

\begin{tabular}{lccll}
\hline Landuse & Area (Sq. m) & Percentage (\%) & $\begin{array}{l}\text { Vulnerability } \\
\text { Rank }\end{array}$ & $\begin{array}{l}\text { Vulnerability } \\
\text { Interpretation }\end{array}$ \\
\hline Waterbodies & 26428311.14 & 10.37 & 3 & High \\
Farmlands/Sparse & 35785889.00 & 14.04 & 2 & Moderate
\end{tabular}




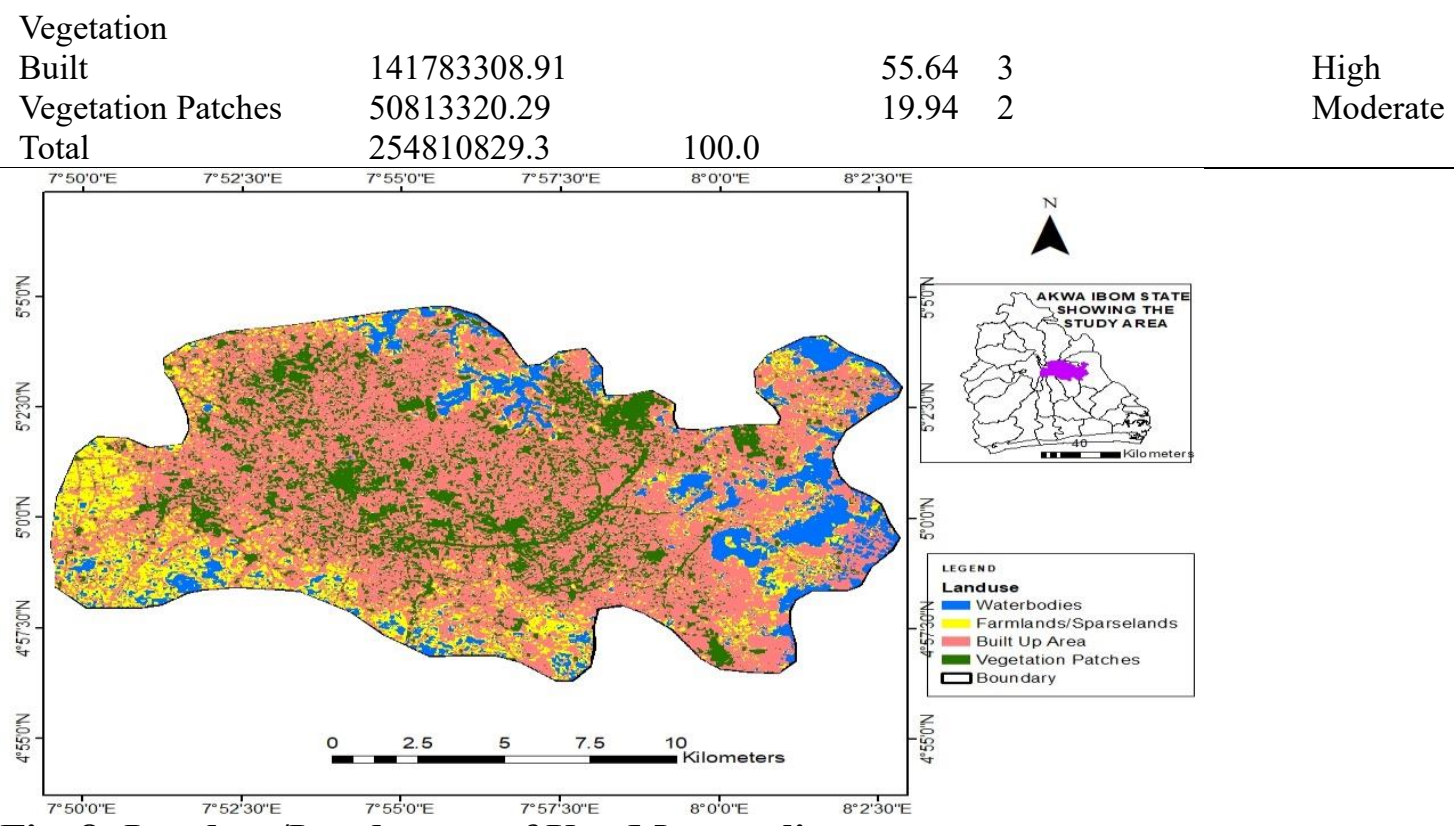

Fig. 8: Landuse/Land cover of Uyo Metropolis

Elevation-based Flood Vulnerability Map

Table 4.25, Figure 4.47, and Figure 4.48 demonstrate the flood susceptibility level based on el evation. It demonstrates that the high susceptibility zone was between 11 and 39 meters above sea level, whereas the moderate vulnerability zone was between 40 and 59 meters. Udo Eduok Street, Abak Road, IBB Way, Afiansit, Ibom Arena, and Ikot Ekpene Road are among the hea vily flooded areas of Uyo. Between 60 and 77 meters was the low vulnerability zone. The high , moderate, and low vulnerability zones covered $160527854.17 \mathrm{~m}^{2}$ (64.45 percent), 73497488 . $63 \mathrm{~m}^{2}$ (29.51 percent), and $15056611.64 \mathrm{~m}^{2}$ (6.04 percent) of the total area, respectively.

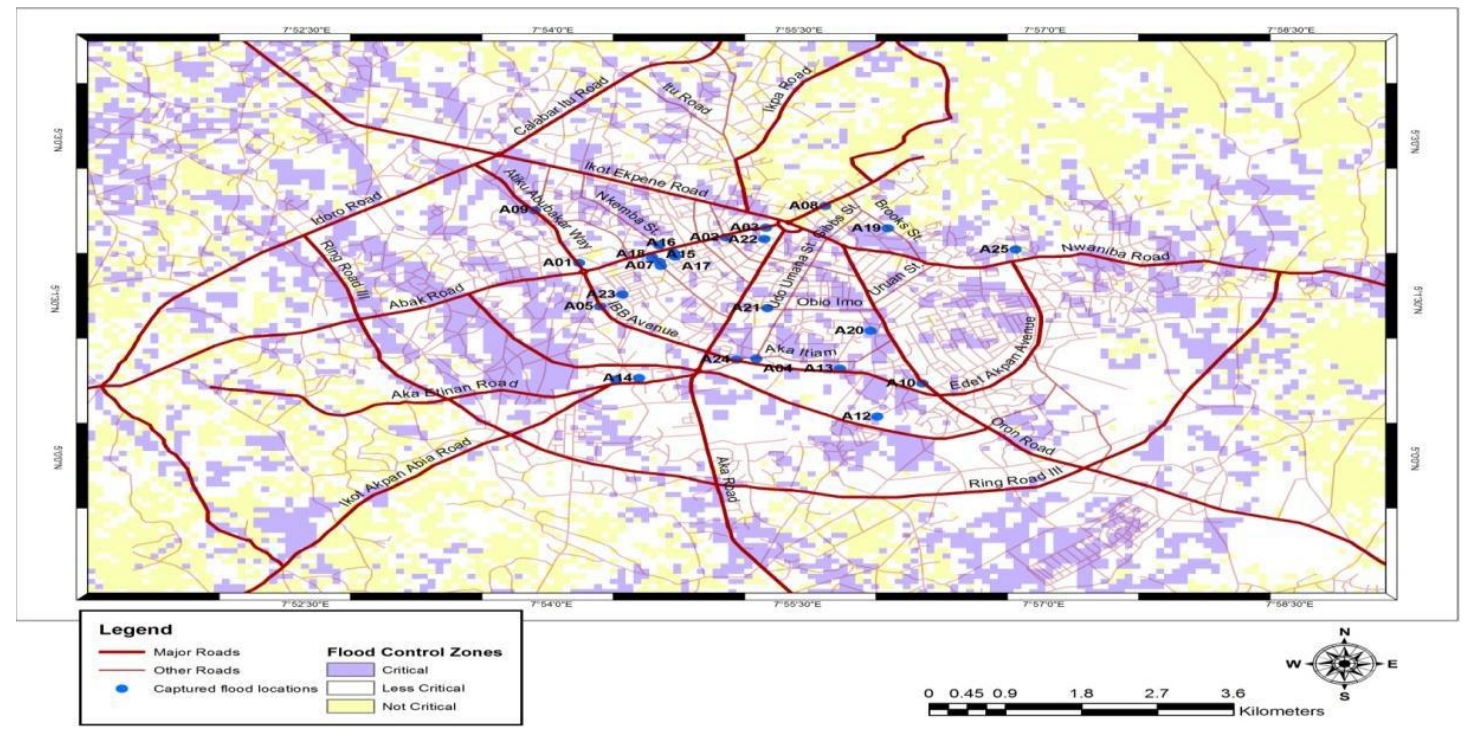

Fig. 9: Highly Flooded zones in Uyo Capital City 
Table 4.24: Elevation data of Uyo Metropolis

\begin{tabular}{|c|c|c|c|c|c|}
\hline $\mathbf{S} / \mathbf{n}$ & Elevation (m) & $\begin{array}{l}\text { Spatial Extent } \\
\left(\mathrm{m}^{2}\right)\end{array}$ & $\begin{array}{l}\text { Percentage } \\
(\%)\end{array}$ & $\begin{array}{l}\text { Vulnerability } \\
\text { Assigned } \\
\text { Values }\end{array}$ & Vulnerability Levels \\
\hline 1 & $11-39$ & 160527854.17 & 64.45 & 3 & High vulnerability \\
\hline 2 & $40-59$ & 73497488.63 & 29.51 & 2 & $\begin{array}{l}\text { Moderate } \\
\text { vulnerability }\end{array}$ \\
\hline 3 & $\begin{array}{l}60-77 \\
\text { Total }\end{array}$ & $\begin{array}{l}15056611.64 \\
249081954.4\end{array}$ & 100.00 & 1 & Low vulnerability \\
\hline
\end{tabular}

\section{Source: Researcher's analysis, 2021}

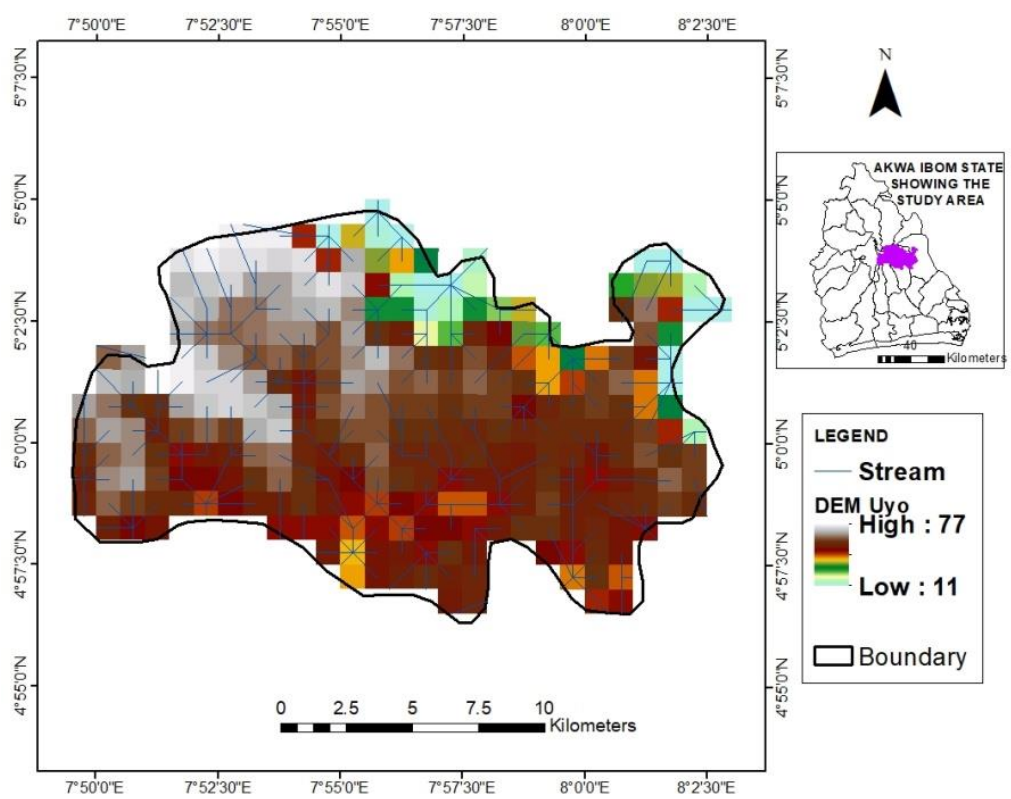

Fig. 10: Elevation of Uyo Metropolis

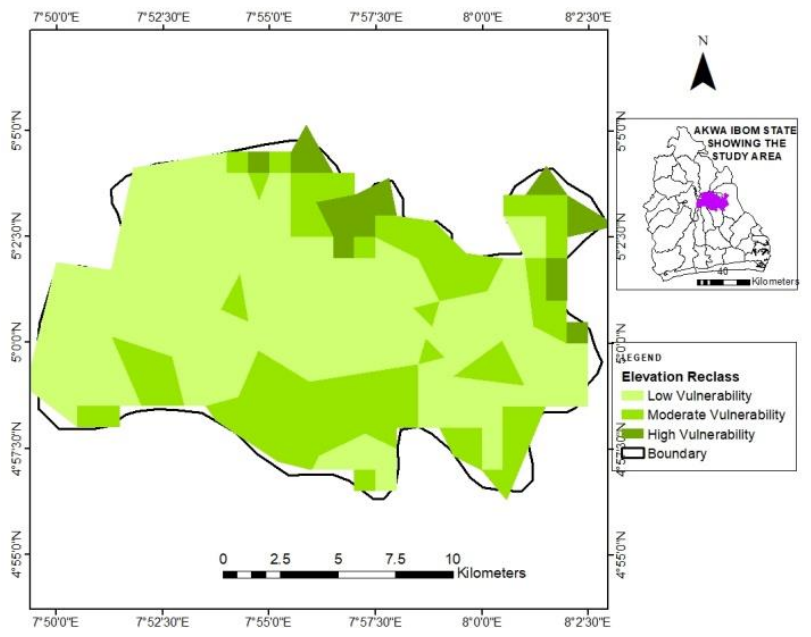

Fig. 11: Elevation Vulnerability of Flood in Uyo

Vulnerability Map of Soil Texture

The soil texture vulnerability to flood in Uyo is described in Table 4.26 and Figures 4.49 and 4.50. The coarse texture covered $15167602.96 \mathrm{~m} 2$, while the fine texture covered 239643226 
$\mathrm{m} 2$, according to the analysis. This translates to 94.05 percent for high vulnerability and 5.95 percent for low vulnerability, respectively.

Table 10: Soil vulnerability of flood in Uyo Metropolis

\begin{tabular}{|c|c|c|c|c|c|}
\hline $\mathbf{S} / \mathbf{n}$ & Soil Texture Type & $\begin{array}{l}\text { Spatial coverag } \\
\text { e }\left(\mathrm{m}^{2}\right)\end{array}$ & $\begin{array}{l}\text { Percentage }( \\
\%)\end{array}$ & $\begin{array}{l}\text { Vulnerability Assig } \\
\text { ned Values }\end{array}$ & $\begin{array}{l}\text { Vulnerability L } \\
\text { evels }\end{array}$ \\
\hline 1 & Coarse Texture & 15167602.96 & 5.95 & 3 & $\begin{array}{l}\text { High vulnerabili } \\
\text { ty }\end{array}$ \\
\hline 2 & Fine Texture & 239643226 & 94.05 & 1 & $\begin{array}{l}\text { Moderate vulner } \\
\text { ability }\end{array}$ \\
\hline Total & & 254810829 & 100.00 & & \\
\hline
\end{tabular}

Source: Researcher's analysis, 2021

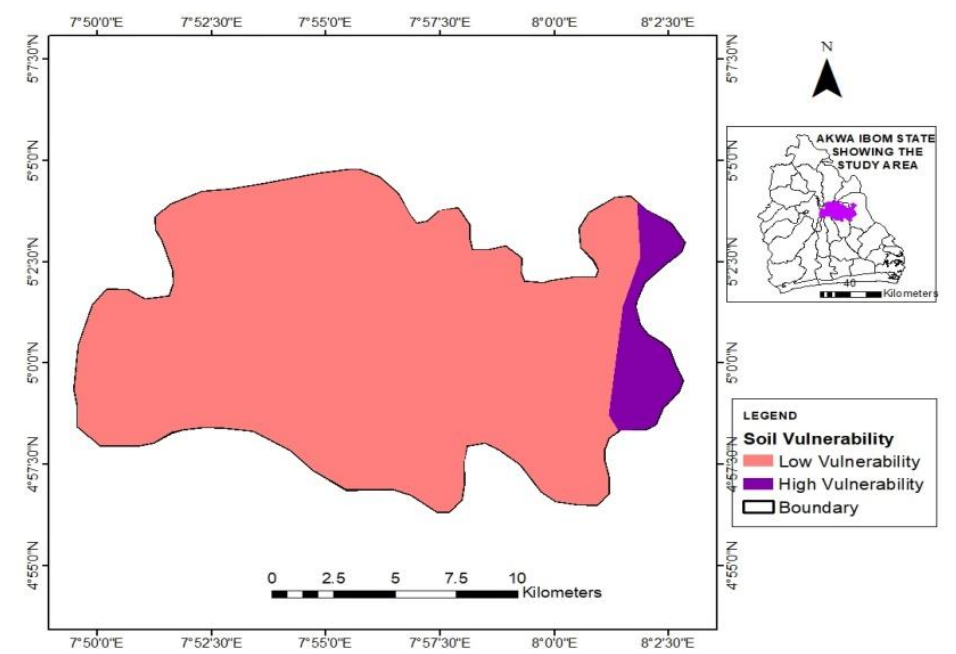

Fig.12: Soil Texture of Uyo Metropolis

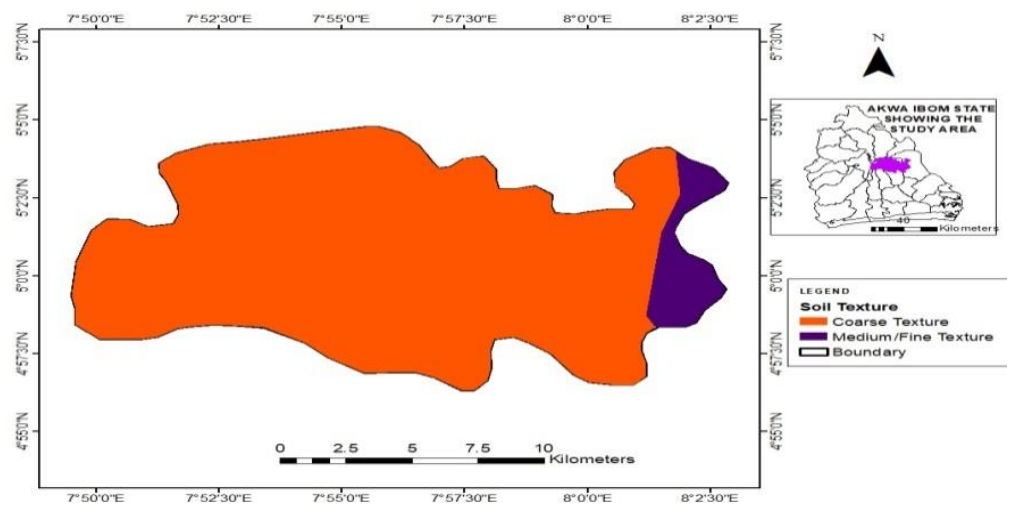

Fig.13: Soil Texture Vulnerability Level to Flood in Uyo

Vulnerability Map of River Channel (Drainage) Proximity

The drainage buffering and drainage vulnerability maps of Uyo are described in Table 4.21 and Figures 4.51 and 4.52, respectively. The results show that the buffer of 200 meters from rivers (i.e. high flood vulnerability level based on proximity to active channel) covered a spatial extent of $57379846.66 \mathrm{~m} 2(20.46 \%)$, the buffer of 400 meters (moderate vulnerability) covered 
$1033867512.24 \mathrm{~m} 2(37.04 \%)$, and the buffer of 600 meters (low vulnerability) covered a spatial extent of $119137260 \mathrm{~m} 2(20.46 \%)$. (42.49 percent ).

Table 11: Drainage vulnerability of flood in Uyo Metropolis

\begin{tabular}{llcccl}
\hline S/n & $\begin{array}{l}\text { Buffer Scen } \\
\text { arios }(\mathrm{m})\end{array}$ & $\begin{array}{l}\text { Spatial cov } \\
\text { erage }\left(\mathrm{m}^{2}\right)\end{array}$ & $\begin{array}{l}\text { Percentag } \\
\text { e }(\%)\end{array}$ & $\begin{array}{l}\text { Vulnerability } \\
\text { Assigned Valu } \\
\text { es }\end{array}$ & $\begin{array}{l}\text { Vulnerabilit } \\
\text { y Levels }\end{array}$ \\
\hline 1 & $0-200$ & 57379846.66 & & 3 & $\begin{array}{l}\text { High vulner } \\
\text { ability } \\
\text { Moderate v }\end{array}$ \\
2 & $200-400$ & $\begin{array}{l}103867512.2 \\
4\end{array}$ & 20.46 & 2 & $\begin{array}{l}\text { Mulnerability } \\
\text { Low vulner } \\
\text { ability }\end{array}$ \\
3 & $400-600$ & 119137260 & 37.04 & 1 & \\
Tota & Total & 280384619.00 & 100.0 & & \\
1
\end{tabular}

\section{Source: Researcher's analysis, 2021}

In Uyo Metropolis, however, the average stream length was shorter. When looking at the number of sub basins in the study region, it was discovered that Uyo had 21.

Table 4.16, figure 4.25 ( $0.00 \mathrm{mins}-01 / 15 \mathrm{mins})$, figure 4.26 ( $1.15 \mathrm{mins}-1.30 \mathrm{mins})$, and figure 4.27 (1.30mins $-6.00 \mathrm{mins}$ ) show the sub catchment runoff, node flooding, and link velocity of Uyo metropolis. In Uyo metropolitan, runoff and floods rose with increasing time of day, while velocity increased from $0.01 \mathrm{ft} / \mathrm{sec}$ to $2 \mathrm{ft} / \mathrm{sec}$ at $1.30 \mathrm{mins}$, then began to decrease and lasted at $1 \mathrm{ft} / \mathrm{sec}$.

Figures 4.28/0.00mins - 03.30mins, 4.29 (03.30mins - 0.400mins), and 4.30 (04.00mins) 06.00mins showed three different large changes in any of the combined parameters over the simulations (runoff, flooding or velocity).

According to the findings, the sub catchment runoff and node flooding remained constant throughout the hour studied (Table 4.17). The link velocity ranged from $10.01 \mathrm{ft} / \mathrm{sec}$ to $0.78 \mathrm{ft} / \mathrm{sec}$ at 3.30 minutes, then climbed to 4.00 minutes for the rest of the day. The study locations' profiles/flood hydrographs were chosen based on the character of the water. Three separate water elevated profiles were created in the city of Uyo. The one from node 36 to out 1 has increased in elevation as the distance to the outfall has increased, whilst the one from node 38 to out 1 has decreased. In Uyo metropolis, the water elevation profile includes node 1 - out 1 (figure 4.33), node 6 to out 1 (figure 4.34), and node 7 to out 1 (figure 4.35). (figure 4.35). Except for the one in Node 6 to out 1, they all continue to descend in elevation as the distance to the outfall increases.

The landuse map vulnerability to flooding according to each landuse identified in the study region presented the analysis and findings for flood vulnerability in Uyo metropolis. The forms of landuse observed and their spatial extents were described by looking at Table 4.18, figure 4.36, and figure 4.37. The investigation also revealed that the area with moderate flood 
susceptibility was $48.7 \%$ of the total, while the area with severe flood vulnerability was 51.3 percent.

The flood susceptibility in Uyo metropolis was disclosed by the analysis and findings, which demonstrated that vulnerability levels were allocated to each landuse found in Uyo metropolitan. The forms of landuse observed and their spatial extents were detailed in Table 4.24, Figure 4.45, and Figure 4.46. Buildup area $(141783308.91 \mathrm{~m} 2)$ vegetation patches $(50813320.29 \mathrm{~m} 2)$. Farmland/space vegetation accounted for $35785889.00 \mathrm{~m} 2$, whereas water bodies and plant patches accounted for 10.37 percent and 19.94 percent, respectively. The studies also revealed that moderate flood susceptibility had a spatial extent of 33.98 percent, while severe flood vulnerability had a spatial extent of 66.02 percent.

\section{Conclusion}

According to the findings, the runoff generated in Uyo was lower. In addition, Uyo's flood risk is lower due to its landuse, height, closeness to the river, and soil texture.

\section{References}

Abam, T,.K.S.; Ofoegbu, C.C. and Gobo, A.E. (2000). Impact of Hydrology in Port Harcourt. Patani Warri Geoscience and Environmental Geology; 40(2), 153 - 162.

Abam, T.K.S, and Gobo A.E. (2014). Post Impact Assessment (PIA) of the 2012 flooding in Some Communities in Rivers State, Nigeria: Proceedings of the 2 International Conference on Flood and Erosion Prevention, Protection and Mitigation, November 2014.

Agumagu, U.D. (2014) Socio-economic impact of 2012 flood in the lower Niger Delta communities of Rivers State and Bayelsa. PhD. Proposal in department of Geography and Environmental Management, University of Port Harcourt.

Ahmadisharaf; E; Kalyanapu, A.J. and Chung, E.S. (2017). Sustainability - Based flood hazard mapping of the Swannanoa Rivershed. Journal of Environmental sustainability: 9(2), 1735 1746

Amangabara, G.T and Obenade, M. (2015). Flood Vulnerability Assessment of Niger Delta State Relative to 2012 Flood Disaster in Nigeria. American Journal of Environmental Protection: 3 (3), 70- 83.

Ameesha, S.B.; Shashi, M. and Pratap, D. (2017). A geo-spatial Approach to Flash Flood Hazard Mapping in the City of Warangal, Telangana, India, Sciendo Environmental Journal: $3(13), 1-13$.

Amro, E; Mohamed, A; Ahmed K., Moustafa K., Nassir A., Anis C. and Kashif N. (2019). Flash Flood Risk Assessment in Urban Arid Environment: Case Study of Taibah and Islamic Universities' Campuses, Medina, Kingdom of Saudi Arabia. Journal of Geomatics, Natural Hazards and Risk:10(1),780-796.

Barasa, B.N. and Pradeep, E.D.P. (2018). Analysis of land use change impacts on flash flood occurrences in the Sosiani River Basin, Kenya. International Journal of River Basin: 16(2), 6182.

Belemina, G. (2009). Disaster Risk: Addressing the Challenge of Natural and Human-Induced Environmental Hazards. Paris, France Press.

Beven, J.K. (2001). Rainfall - Run-off Modeling. England: Willey Publisher. 
Bhatt, C.M; Rao, G.S; Manjushree, P; and Bhanumurthy, V. (2010). Space Based Disaster Management of 2008 Kosi Flood, North Bihar, India. Journal of Indian Soc. Rem. Seus: 38(1), 79-108.

Birkmann, J. (2006). Measuring Vulnerability to Promote Disaster-Resilient Societies: Conceptual Frameworks and Definitions. Measuring Vulnerability to Natural Hazards: Towards Disaster Resilient Societies. Tokyo, United Nations University Press: 9-54.

Bitew, G.T; Mulugata, A.B. and Miegel, K. (2019). Application of HEC - HMS Model for Flow simulation in the bike Tana Basin; The case of Gilgel Abay Catchment, Upper Blue Nile Basin, Ethiopia. Journal of Hydrology: 2(21), 2-17.

Brown, I. and Tari, E. (2017). Towards an effective storm water management in Yenegoa City, Bayelsa State. Journal of Scientific and Engineering Research: 4(1), 177-188.

Dawod, G.M; Mirza, M.N; and Al-Ghamdi, K.A. (2011). GIS-Based Spatial Mapping of Flood Hazard in Makkali City Saudi Arabia. Journal of Geographic Information System: 11(3), 225231.

Debarry, P.A. (2004). Watershed: Processes, Assessment and Management. New York. John Willey and Sons.

Ede P.N. and Utchay O. (2014).Urban Flood Management Scenarios in Port Harcourt : Proceeding of the 2nd International Conference on Flood and Erosion Prevention, Protection and Mitigation, Nov 2014. (www.ust.edu.ng)

El-Basfaxodesy, M; White, K; and Nasr, A. (2009). Integration of Remote Sensing and GIS for Modeling Flash Flood in Wadi Hudien Catchment, Egypt. Journal of Hydrological Processes: 23(9), 1359 - 1368.

Eyinla, P. and Ukpo, J. (2006). Nigeria: The Travesty of Oil and Gas Wealth Lagos: The Catholic Secretariat of Nigeria.

Eze, B.E. and Abua, M.A. (2002). Environmental Hydrology. Calabar. Ushie Printers and Publisher Company Limited.

Fateye, O.C.A. and Olaschinde, O. B.A. (2016). Mapping Vulnerability of Flash Flood in Ado Ekiti. Journal of Humanities and Social Sciences: 21(2), 65-72.

Forkuo, E.K. (2011). Flood Hazard Mapping Using Aster Image Data with GIS. International Journal of Geometrics and Geosciences: 1(4), 326 - 334.

Fubara, M.J.(2014): River Hydrodynamics and Sea Level Monitoring For Flood Impact Control In The Niger Delta, Proceedings of the 2 International Conference on Flood and Erosion Prevention, Protection and Mitigation, November 2014. [www.ust.edu.ng]

Ghoneina, E.M; Arnell, N.W. and Foody, G.M. (2002). Characterizing the Flash Flood Hazards Potential along the red sea Coast of Egypt. The Exthemes of the Extremes: Extraordinary Floods (Proceedings of a Symposium held at Reykjarik, Icedand).

Graf, A. (2014). Spatio-Temporal Relations between water bridge components and soil water content in a forested tributary catchment resource research: 50(6), 60-72.

Hapuarachichi, HAP; Wang, Q.J. and Pagano, T.C. (2011). A Review of Advances in Flash Flood Forecasting: Hydrol. Process: 25(3), 2771-2784: Retrieved 28/10/2019 from 
http://Dx:Doi.org/10:1002/hyp.8040.

Hayder, A.A. \& Husam, A.A. (2013). Maximum Likelihood for land use / land cover mapping and change detection using Landsat satellite images: A case study "South of Johor. International Journal of Computational Engineering Research, 3(6), 26-33.

IMGW, (2013). Institute of Meteorological and Water Management, Report on Plan and Policy Statement.

Ismail, E. (2015). Flash Flood Hazard Mapping Using Satellite Images and GIS Tools: A Case Study of Najran City, Kingdom of Saudi Arabia (KSA). The Egyptian Journal of Remote Sensing and Space Sciences: 18(3), 261-278.

Leonard, I.U. and Dorathy, I.U. (2013). Gender, Floods and Mental Health. The Way Forward. An International Journal of African Social Sciences: 3(4), 1030 - 1042.

Lian, J; Yang, W; Xu, K. \& Ma, C. (2017). Flash flood vulnerability assessment for small catchments with a material flood approach. Natural Hazard: 88(2), 699-719

Liang, W. Yongli, C; Hongquan, C; Daler, D; Jingmin, Z. and Juan, Y. (2011). Flood Disaster in Talibu basin, China: Causal Chain and Policy Option Analysis Environment and Earth Science: 63(5), $1119-1124$.

Marzieli, S.H; Fateme, Z; Ali, B. and Ali, M. (2014). Flood assessment in the context of sustainable development using the APSIR Framework. International Journal of Environmental Protection and Policy: 2(2); 41-49.

Mastin, M. (2009). Watershed Models for Decision Support for Inflows to Potholes. Washington D.C. M.C Grawhill.

Mohammed, A.J; Abbas, B; and Abel, A.A. (2016). Spatial Distribution Pattern and Terrain Analysis of urban flash flood and inundation Areas in Maiduguri Metropolis, Borno State, North East, Nigeria.

Mohammed, A; Amro, E; Ahmed, K; Monstafa, K; Nassir, A; Anis, C. and Kaslrit, N. (2019). Flash Flood Risk Assessment in Urban Arid Environment: Case Study of Tarbah and Islamic Universities Campuses, Medina, Kingdom of Saudi Arabia (KSA). Journal of Geomatics, Natural Hazards and Risk: 10(1), 780-796. Retrieved on 05/11/2019 from http://doi.org/10./080/1947505:2018.1545705.

Muneerudeen, A. (2017). Urban Landscape Design Strategies for Flood Resilience in Chennai City: Qatar University: Doha Patar.

National Emergency Management Agency (NEMA) (2012) Report on Flood Disaster.

NPC, (2006). National Population Commission Report for 2006 Census Exeecial.

NPC, (2019). National Population Commission Annual Projection 2019 for cities and staets in Nigeria.

Odeyemi, C.A. \& Olabode, B.A.D. (2016). Mapping Vulnerability to Flash Flood in Ado-Ekiti. JOSR Journals of Humanities and Social Sciences: 21(2)65-72

Olabode, B.J. (2014). Impact of River Niger Flooding on the Inhabitants of Lokoja and its Environs: International Conference on Flood and Erosion Prevention, Protection and Mitigation. November, 2014. 
Ologunorisa, T.E. and Abawua, M.J. (2005) . Flood Risk Assessment: A Review Department of Geography, Benue State University, Makurdi. Journal of Applied Sciences and Environmental Management and Mitigation Options for Nigeria: Proceedings of the $2^{\text {nd }}$ International Conference on Flood and Erosion Prevention, Protection and Mitigation, November, 2014.

Olowu, D. (2010). The Hyogo Framework for Action and its implications for Disaster Management and Education in Africa. JAMBA: Journal of Disaster Risk Studies, 3(1):303-320

Oyebande, L.(2014).Integrated Flood Management and Mitigation options for Nigeria: Proceedings of the 2nc International Conference on Flood and Erosion Prevention, Protection and Mitigation, November 2014.

Oyegun, C.U. (1994). Geology and Sedimentary Environment in Oyegun and Adeyemo (e.d) Port Harcourt Region. University of Port Harcourt Publication series No. 1.

Oyegun, C.U. (2003). Essentials of Social and Environmental Research, Port Harcourt: University of Port Harcourt.

Pagano, T. and Sorooshian, S. (2002). Hydrologic Cycle. Encyclopedia of Global Environment Change.

Subramanya, K. (2008). Engineering Hydrology, New York, McGraw Hill Press.

Sunmin, L; Saro, L; Moung-Jin, L. and Hyund-Sup, L. (2018). Spatial Assessment of Urban Flood Susceptibility Using Data Mining and Geographic Information System (GIS) Tools. Sustainability Journal, 10(3), 648-655.

Uchenna, E.O. (2013) Perception of flood Disaster risk reduction and Adaptation Strategies in Port Harcourt Metropolis. M.Sc thesis, department of Geography and Environmental Management University of Port Harcourt.

Umeuduji .J.E (2010) Drainage Basin Dynamics, Ehai Books, Published in Nigeria, University of Port Harcourt

UN, (2009). United Nations World Water Development Report 3. Water in a changing world. The United Nations Educational Scientific and Cultural Organization (UNESCO).

Weli, V.E (2004) Urban Flood Prediction in the Niger Delta. A case study of Port Harcourt metropolis, M.sc Thesis Submitted to the department of geography and environmental management, university of Port Harcourt

Woubet, G.A. and Belachew, D.L. (2011). Flood Hazard and Risk Assessment Using GIS and Remote Sensing in Fogera Woreda, Northwest Ethiopia. Department of Natural Resources Management, Blaire Dar University Blaire Dari, Ethiopia.

Youssef, A.M; Pradhan, B; and Sefry, S.A. (2016). Flash flood susceptibility Assessment in Jeddah City, Kingdom of Saudi Arabia, using Bivariate and Multivariate Statistical Models. Journal of Environmental Earth Science: 75(12), 161 - 182.

\section{Copyrights}

Copyright for this article is retained by the author(s), with first publication rights granted to the journal.

This is an open-access article distributed under the terms and conditions of the Creative Commons Attribution license (http://creativecommons.org/licenses/by/4.0/) 